\title{
Hubungan Tindakan Kesehatan Gigi Dan Mulut Pasien Terhadap Kepatuhan Dalam Menjalani Perawatan Berulang
}

\author{
(Relations Between Dental Health Action On Patient Compliance In Repeated \\ Treatment)
}

\author{
Ahmad Mujahidin ${ }^{1}$, dan Galih Sampoerna ${ }^{2}$ \\ ${ }^{1}$ Mahasiswa Pendidikan Dokter Gigi \\ ${ }^{2}$ Staf Pengajar Departemen Konservasi Gigi \\ Fakultas Kedokteran Gigi Universitas Airlangga \\ Surabaya-Indonesia Bagian Konservasi Gigi
}

\begin{abstract}
Background. Oral health problems in the community one of them is behavioral factors of oral hygiene. It is associated with the treatment that requires patients to make treatment stages that can't be resolved by the operator in a single visit. Treatment done by because there are some conditions such as emergency cases, complicated and requires a lot of time. Purpose. The aim of the study was look at the relationship between dental health measures to compliance with repeated treatments. Method. This study is an observative analytical research using cross sectional design. research is divided into two parts, to find level of dental health action and Patient Compliance In Repeated Treatment. Level of oral hygiene of patients is knew by questionnaire. Compliance is measured by looking at the card status of patients. Result. Found $45.71 \%$ of respondents have a high health measures on dental health, while another $11.43 \%$ having low health measures on dental and oral health. Then there is also a health measure as much as $42.86 \%$ of patients who were. A total of $68.57 \%$ of people dutifully repeated during treatment and no patient who did not obey repeated during treatment. A total of 11 patients from 35 patient trial (31.43\%) patient compliance in a state of being. Once associated with poorer spearman correlation test statistic p-value $=0.882$. Conclusion. There was no significant relationship between dental health action patient on patients compliance in repeated treatments. It is seen from the p-value $>0.05$ in spearmen correlation of test results.
\end{abstract}

Keywords: Dental Health Action, Patient Compliance, Repeated Treatment

Korespondensi (correspondence): Ahmad Mujahidin, Bagian Konservasi Gigi, Fakultas Kedokteran Gigi Universitas Airlangga, Jl. Mayjen Prof. Moestopo 47 60132, Indonesia. E-mail: mj_hyden90@yahoo.com.

\section{PENDAHULUAN}

Program kesehatan nasional merupakan strategi yang mengutamakan pelaksanaan pembangunan nasional berwawasan kesehatan. Program ini memberikan prioritas terhadap upayaupaya peningkatan pelayanan kesehatan (promotif). kemudian upaya pencegahan penyakit (preventif). dan upaya pemulihan atau penyembuhan penyakit (rehabilitatif). yang dilakukan secara menyeluruh, terpadu dan berkesinambungan. Program ini memuat kesehatan gigi dan mulut. Kesehatan gigi dan 
mulut merupakan bagian dari kesehatan tubuh yang tidak dapat dipisahkan satu dengan yang lainnya. ${ }^{1,2}$

Masalah kesehatan gigi dan mulut pada masyarakat salah satunya adalah faktor perilaku atau sikap mengabaikan kebersihan gigi dan mulut. Perilaku kesehatan merupakan salah satu faktor yang berpengaruh terhadap kesehatan gigi individu atau masyarakat. ${ }^{3}$ Domain penting dalam perilaku adalah tindakan. Tindakan adalah bentuk respon aktif dapat berupa perilaku yang nyata. Tindakan merupakan hasil pelaksanaan yang berdasarkan pada domain lain dalam perilaku seperti pengetahuan dan sikap. ${ }^{4}$

Perawatan berulang adalah perawatan yang menuntut penderita untuk melakukan tahapan perawatan yang tidak bisa diselesaikan oleh operator dalam sekali kunjungan. Perawatan dilakukan oleh karena ada beberapa kondisi seperti kasus darurat, rumit dan memerlukan banyak waktu. ${ }^{5}$ Banyaknya kunjungan yang diperlukan untuk perawatan, mengakibatkan perawatan terkadang tidak tuntas karena ketidakpatuhan penderita sendiri. Hal ini dikarenakan bentuk tindakan kesehatan berupa keengganan pasien datang berkali-kali dan ketidaktahuan pasien tentang bagaimana pentingnya tahapan-tahapan yang terdapat dalam suatu perawatan.

Pasien tidak datang kembali setelah dilakukan tindakan relief of pain oleh operator, karena pasien sudah tidak merasa sakit lagi. Ketidakpatuhan dalam menjalani perawatan di bidang konservasi gigi dapat menyebabkan kegagalan perawatan yang berakibat perawatan harus diulang kembali. Hal ini berarti menambah biaya dan waktu baik untuk pasien maupun dokter gigi sendiri. perlu komunikasi dan edukasi dari dokter kepada pasien dengan baik agar pasien memperbaiki tindakan yang mengarah pada kesehatan, sehingga berdampak pada peningkatan kepatuhan pasien terhadap perawatan yang dilakukan.

\section{BAHAN DAN METODE}

Penelitian ini merupakan analitik observatif dengan jumlah sampel 35 pasien usia 12-60 tahun yang enderita yang sedang menjalani perawatan berulang di RSGM-P Fakultas Kedokteran Gigi Universitas Airlangga (dengan minimal 3-4x kunjungan). Tindakan diukur dengan pemberian skor pada jawaban kuisioner yang telah diisi oleh responden berjumlah 6 buah kuisioner. diberi Skor 1 bila jawaban benar, dan 0 jika jawaban salah. Kemudian hasil diberi 3 kriteria. Baik jika total nilai antara 5-6, Sedang jika total nilai antara 3-4 dan Rendah jika total nilai antara 1-2. Kepatuhan penderita dilakukan pengukuran dengan menilai ketepatan waktu datangnya penderita sesuai dengan jadwal kunjungan, kesesuaian jumlah kunjungan dengan rencana awal, kesesuaian perawatan dengan rencana perawatan, dan tingkat kooperatif penderita terhadap operator. Kemudian hasilnya dibagi dalam beberapa kriteria Patuh jika total nilai 4, kurang patuh jika otal nilai 1-3 dan tidak patuh jika total nilai 0 . Kemudian keduanya di uji hubungannya dengan uji statistik pearson correlation.

\section{HASIL}

Tindakan adalah apa yang dilakukan responden terkait dengan kesehatan, yaitu diantaranya pencegahan penyakit (preventif), cara memperoleh pengobatan yang tepat (kuratif), cara peningkatan kesehatan (rehabilitatif). ${ }^{4}$

Berdasarkan data yang dihimpun dari hasil kuisioner. Hasil tersebut dikategorikan dalam tiga karakteristik yaitu tinggi, sedang dan rendah, adalah sebagai berikut:

Tabel1: Distribusi responden berdasarkan hasil kuisioner tindakan kesehatan gigi.

\begin{tabular}{|l|r|r|}
\hline $\begin{array}{c}\text { Tindakan kesehatan } \\
\text { gigi Penderita }\end{array}$ & \multicolumn{1}{|c|}{$\begin{array}{c}\text { Jumlah } \\
(\mathrm{N})\end{array}$} & \multicolumn{1}{c|}{$\begin{array}{c}\text { Prosentase } \\
(\%)\end{array}$} \\
\hline Tinggi & 16 & 45,71 \\
\hline Sedang & 15 & 42,86 \\
\hline Rendah & 4 & 11,43 \\
\hline Total & 35 & 100 \\
\hline
\end{tabular}

Hasil kuisioner menunjukkan bahwa sebanyak $45,71 \%$ responden memiliki tindakan kesehatan yang tinggi tentang kesehatan gigi dan mulut, sedangkan $11,43 \%$ yang lain memiliki tindakan kesehatan yang rendah tentang kesehatan gigi dan mulut. Kemudian juga terdapat sebanyak $42,86 \%$ tindakan kesehatan penderita dalam tataran sedang.

Kepatuhan dalam perawatan kesehatan dapat diartikan sebagai ketaatan, kooperatif, saling pengertian, dan hubungan terapeutik. Sebagian besar definisi memasukkan elemen tanggung jawab penderita terhadap perawatan 
dirinya, peran terhadap proses pengobatan dan kerja sama dan interaksi penderita dengan petugas kesehatan. ${ }^{6}$

Tabel 2. Distribusi responden berdasarkan kepatuhan

\begin{tabular}{|l|r|r|}
\hline \multicolumn{1}{|c|}{$\begin{array}{c}\text { Kepatuhan } \\
\text { Penderita }\end{array}$} & \multicolumn{1}{|c|}{$\begin{array}{c}\text { Jumlah } \\
(\mathrm{N})\end{array}$} & $\begin{array}{c}\text { Prosentase } \\
(\%)\end{array}$ \\
\hline Patuh (4) & 24 & 68,57 \\
\hline kurang patuh (1-3) & 11 & 31,43 \\
\hline Tidak patuh (0) & 0 & 0 \\
\hline Total & 35 & 100 \\
\hline
\end{tabular}

Hasil penelitian menunjukkan bahwa sejumah besar penderita, yakni $68,57 \%$ adalah patuh selama perawatan berulang dan tidak ada penderita yang tidak patuh selama perawatan berulang. Tercermin pula bahwa sebanyak 11 penderita dari 35 penderita coba $(31,43 \%)$. kepatuhan penderita dalam keadaan sedang.

Tingkat tindakan kesehatan penderita yang tergambarkan dalam tabel sebelumnya melalui hasil jawaban dari kuisioner kemudian dihubungkan dengan tingkat kepatuhan yang telah dihimpun berdasarkan kriteria yang sudah ditetapkan.

Tabel 3: Distribusi responden berdasarkan tingkat tindakan kesehatan dengan kepatuhan penderita

\begin{tabular}{|l|r|r|r|r|r|r|}
\hline \multirow{3}{*}{ Tindakan } & \multicolumn{6}{|c|}{ Kepatuhan } \\
\cline { 2 - 7 } & \multicolumn{2}{|c|}{ Patuh } & \multicolumn{2}{|c|}{ Sedang } & \multicolumn{2}{c|}{$\begin{array}{c}\text { Tidak } \\
\text { patuh }\end{array}$} \\
\cline { 2 - 7 } & $\mathrm{N}$ & \multicolumn{1}{|c|}{$\%$} & \multicolumn{1}{c|}{$\mathrm{N}$} & \multicolumn{1}{c|}{$\%$} & $\mathrm{~N}$ & $\%$ \\
\hline Tinggi & 12 & 34,29 & 4 & 11,43 & 0 & 0 \\
\hline Sedang & 10 & 28,57 & 5 & 14,29 & 0 & 0 \\
\hline Rendah & 2 & 5,71 & 2 & 5,71 & 0 & 0 \\
\hline
\end{tabular}

Diketahui bahwa sebanyak 34,29\% responden dengan tingkat tindakan kesehatan tinggi dan patuh terhadap perawatan berulang yang sedang dijalankan. Tergambar pula $11,43 \%$ penderita dengan tingkat tindakan kesehatan tinggi namun memiliki kepatuhan yang sedang. Kemudian sebanyak 28,57\% penderita dengan tingkatan tindakan yang sedang tapi patuh. Selain itu, sebanyak $14,29 \%$ penderita dengan tindakan yang sedang memiliki kepatuhan yang sedang pula . Sebanyak $5,71 \%$ penderita dengan tingkat tindakan kesehatan gigi rendah namun penderita patuh. Sebanyak $5,71 \%$ responden dengan tingkat tindakan kesehatan yang rendah dan kepatuhan selama perawatannya sedang.
Berdasarkan data yang didapat dari responden dari tingkat tindakan dan kepatuhan, kemudian dicari hubungan antara tingkat tindakan kesehatan gigi terhadap kepatuhan menjalani perawawatan berulang. Hasil uji statistik spearman correlation ditemukan bahwa tidak ada hubungan yang signifikan antara keduanya, hal tersebut ditunjukkan melalui nilai p sebesar 0,865.

\begin{tabular}{|c|c|c|c|l|}
\hline $\begin{array}{c}\text { Variabel } \\
1\end{array}$ & $\begin{array}{c}\text { Variabel } \\
2\end{array}$ & $\begin{array}{c}\text { Nilai } \\
\mathrm{p}\end{array}$ & $\begin{array}{c}(\mathrm{p} \\
<0,05)\end{array}$ & Keterangan \\
\hline $\begin{array}{r}\text { Tindakan } \\
\text { kesehatan }\end{array}$ & Kepatuhan & 0,865 & $\mathrm{p}>0,05$ & $\begin{array}{l}\text { Tidak ada } \\
\text { hubungan } \\
\text { yang } \\
\text { signifikan }\end{array}$ \\
\hline
\end{tabular}

Selain tindakan kesehatan gigi pasien, penelitian dengan variabel lain yang mungkin berpengaruh dengan kepatuhan juga dilakukan, diantaranya pendidikan, motivasi, kebutuhan, persepsi pembiayaan dan hubungan kekerabatan antara operator dan pasien. Dengan menggunakan uji pearson correlation dapat ditemukan hasil sebagai berikut.

\begin{tabular}{|c|c|c|l|}
\hline Variabel 1 & Variabel 2 & $\mathrm{p}$ & Keterangan \\
\hline Pendidikan & Kepatuhan & 0,119 & $\begin{array}{l}\text { Tidak ada } \\
\text { hubungan } \\
\text { yang } \\
\text { signifikan }\end{array}$ \\
\hline Motivasi & Kepatuhan & 0,006 & $\begin{array}{l}\text { Ada } \\
\text { hubungan } \\
\text { yang } \\
\text { signifikan }\end{array}$ \\
\hline Kebutuhan & Kepatuhan & 0,020 & $\begin{array}{l}\text { Ada } \\
\text { hubungan } \\
\text { yang } \\
\text { signifikan }\end{array}$ \\
\hline Persepsi & Kepatuhan & 0,018 & $\begin{array}{l}\text { Ada } \\
\text { hubungan } \\
\text { yang } \\
\text { signifikan }\end{array}$ \\
\hline Pembiayaan & Kepatuhan & 0,034 & $\begin{array}{l}\text { Ada } \\
\text { hubungan } \\
\text { yang } \\
\text { signifikan }\end{array}$ \\
\hline $\begin{array}{c}\text { Hubungan } \\
\text { Kekerabatan }\end{array}$ & Kepatuhan & 0,921 & $\begin{array}{l}\text { Tidak ada } \\
\text { hubungan }\end{array}$ \\
\hline
\end{tabular}




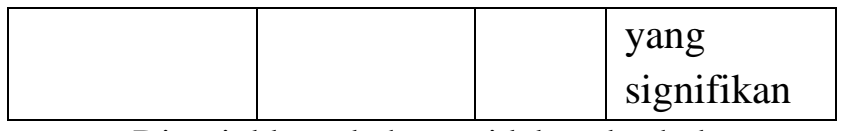

Ditunjukkan bahwa tidak ada hubungan yang signifikan antara pendidikan dan hubungan kekerabatan dengan kepatuhan penderita. Namun ditemukan adanya hubungan yang signifikan antara motivasi, kebutuhan, persepsi, dan pembiayaan dengan kepatuhan penderita dalam menjalani perawatan berulang.

\section{PEMBAHASAN}

Secara operasional, perilaku adalah respon seseorang terhadap rangsangan dari luar subjek tersebut. Respon ini berbentuk dua macam, yaitu bentuk pasif yang merupakan respon internal dan bentuk aktif yang merupakan perilaku yang dapat diobservasi secara langsung. Bentuk respon aktif dapat berupa tindakan yang nyata. ${ }^{4,7}$

Tindakan merupakan respon aktif dari perilaku seseorang. Tindakan merupakan apa yang dilakukan responden terkait dengan kesehatan, yaitu diantaranya pencegahan penyakit (preventif), cara memperoleh pengobatan yang tepat (kuratif), cara peningkatan kesehatan (rehabilitatif). Dari ketiga bentuk tindakan tersebut tentunya berdampak pada perilaku penderita untuk menjalani perawatan dengan patuh. ${ }^{8}$ Namun, hasil penelitian menunjukkan bahwa tidak ada hubungan linier antara tindakan kesehatan gigi terhadap kepatuhan penderita. Hal ini dapat dilihat pada Tabel 5, diketahui bahwa sebanyak 34,29\% responden dengan tingkat tindakan kesehatan tinggi dan patuh terhadap perawatan berulang yang sedang dijalankan. Tergambar pula $11,43 \%$ penderita dengan tingkat tindakan kesehatan tinggi namun memiliki kepatuhan yang sedang. Kemudian sebanyak $28,57 \%$ penderita dengan tingkatan tindakan yang sedang tapi patuh. Selain itu, sebanyak 14,29\% penderita dengan tindakan yang sedang memiliki kepatuhan yang sedang pula . Sebanyak 5,71\% penderita dengan tingkat tindakan kesehatan gigi rendah namun penderita patuh. Sebanyak 5,71\% responden dengan tingkat tindakan kesehatan yang rendah dan kepatuhan selama perawatannya sedang.

Tingkat kepatuhan penderita dalam penelitian ini menunjukkan bahwa 68,57\% responden patuh dalam menjalani perawatan berulang, kemudian sekitar $31,43 \%$ memiliki kepatuhan sedang dan tidak ada penderita yang tidak patuh selama menjalani perawatan berulang (Tabel 3). Kepatuhan penderita dalam penelitian ini dinilai dari ketepatan waktu dan jumlah kedatangan penderita dalam menjalani perawatan, kesesuaian tahapan perawatan dengan rencana perawatan serta tingkat kooperatif penderita. Kim (1983) memberi gambaran tentang hal-hal yang mempengaruhi diantaranya seperti paksaan, kecocokan terapi atau kesepakatan terapi (Kyngas et. al, 2000). Kemudian kepatuhan juga disimpulkan melalui persetujuan penderita terhadap petunjuk pengobatan berupa perancanaan perawatan, jadwal pengobatan, kerjasama yang baik dari penderita (Evangelista, 1999).

Hasil uji statistik Spearman Correlation menunjukkan bahwa tidak ada hubungan yang signifikan antara tindakan kesehatan gigi terhadap kepatuhan dalam menjalani perawatan berulang di UPF Konservasi Gigi RSGMP Fakultas Kedokteran Gigi Universitas Airlangga pada periode bulan September hingga November 2011, hal ini ditunjukkan dengan nilai $p=0,882$. Hasil penelitian ini tidak sejalan dengan berbagai teori yang ada, antara lain teori perubahan perilaku Notoadmodjo ( 2007), yang menyebutkan bahwa tindakan yang merupakan respon aktif sangat mempengaruhi terbentuknya tindakan dan perilaku sehat, dalam hal ini kepatuhan dalam menjalani perawatan berulang.

Tingkat tindakan kesehatan gigi penderita tidak berhubungan secara signifikan terhadap kepatuhan dikerenakan kepatuhan disebabkan oleh banyak faktor seperti penelitian yang dilakukan Widagdo (2003). Melalui data yang dihimpun, ditemukan pula bahwa ada beberapa faktor pemungkin yang berpengaruh di RSGM UPF Konservasi Gigi meliputi pembiayaan (pvalue $=0,34)$ motivasi ( -value $=0,006$ ), kebutuhan (p-value $=0,020)$, dan persepsi ( $\mathrm{p}$ value $=0,018)$. Sedangkan faktor hubungan kekerabatan ( $\mathrm{p}$-value $=0,921)$ dan pendidikan ( $\mathrm{p}$ value $=0,119)$ tidak berhubungan secara signifikan.

Faktor-faktor yang mungkin berpengaruh terhadap kepatuhan dapat dibagi dalam beberapa bagian yaitu faktor predisposisi, faktor pemungkin dan faktor penguat, faktor faktor tersebut telah diteliti oleh Wahyu Widagdo (2003) $)^{4}$ namun dengan sample penderita tuberculosis namun dengan kriteria sama dengan penelitian ini yakni menjalani perawatan berulang. Faktor predisposisi meliputi rentang usia, jenis kelamin, pekerjaan, pendidikan pengetahuan dan sikap. Sedangkan dari faktor pemungkin terdiri dari jarak rumah ke rumah sakit dan ketersediaan transportasi. Kemudian dari faktor penguat terdiri atas dukungan keluarga dan pelayanan operator. 
Faktor predisposisi kepatuhan mengacu pada Robin (2004), yang berpendapat bahwa faktor demografi dapat berpengaruh pada kepatuhan, yaitu diantaranya usia, jenis kelamin, pendidikan dan penghasilan. Menurut Widagdo (2003) dalam tesisnya menyebutkan bahwa faktor usia cukup memiliki pegaruh terhadap kepatuhan, yaitu usia lebih tua lebih tidak patuh dari usia yang lebih muda, namun tercatat tidak dominan dan signifikan.ketidakpatuhan penderita pada usia lebih tua dikaitkan dengan kesibukan. ${ }^{9}$ Kemudian berdasarkan jenis kelamin tercermin bahwa wanita cenderung lebih patuh menurut Shea et,all (1997). ${ }^{9}$ Keadaan ini dikaitkan dengan kecenderungan waktu lenggang wanita daripada pria dan kekhawatiran ibu rumah tangga bila menularkan penyakitnya. Namun dalam penelitian, tidak ada hubungan yang signifikan antara jenis kelamin dan kepatuhan penderita. Dari segi pendidikan menurut Widagdo pula disebutkan tidak ada hubungan yang signifikan antara tingkat pendidikan penderita dengan kepatuhan. Hal tersebut dikarenakan faktor informasi dapat diperoleh dari media-media dan penyuluhan sehingga jenjang pendidikan tertentu tidak bisa menjadi jaminan sebagai penentu kepatuhan. ${ }^{10}$ Hal tersebut pula dipertegas oleh Marzuki (2000) yang menyebutkan tidak ada hubungan antara tingkat pendidikan penderita baik yang pada tingkat dan dasar maupun yang tingkat menengah kepada kepatuhan penderita dalam menjalani perawatan berulang. Dari segi pengetahuan, menurut Marzuki (2000) tingkat pengetahuan penderita memiliki hubungan yang signifikan terhadap kepatuhan penderita dalam menjalani perawatan berulang. Dari segi sikap penderita menurut Cameroon (1996) terdapat hubungan yang signifikan antara sikap dan kepatuhan. Hal tersebut dihubungkan dengan keadaan bahwa sikap merupakan elemen pembentuk sikap seseorang dalam hal ini kepatuhan. ${ }^{10,11 \text {, }}$

Faktor pemungkin terdiri dari jarak rumah ke rumah sakit dan ketersediaan transportasi. Dari segi pekerjaan disebutkan bahwa terdapat hubungan yang signifikan antara penderita yang bekerja dan penderita yang tidak bekerja, yang mana penderita yang bekerja cenderung lebih patuh. ${ }^{10}$ Shea (1997) menegaskan bahwa pasien yang tidak bekerja kepatuhannya lebih buruk dari yang bekerja. ${ }^{9}$ Semnani (1996) berpendapat bahwa kemiskinan atau tingkat sosial ekonomi yang rendah dapat mempengaruhi kepatuhan penderita. Philipus (1997) juga mengutarakan bahwa ada hubungan yang signifikan antara ketersediaan transportasi karena mempengaruhi keteraturan dalam berobat. ${ }^{10}$

Beberapa faktor penguat kepatuhan yakni berupa dorongan dari keluarga dan pelayanan dari operator. Faktor dorongan dari keluarga mengalami kendala karena sulit untuk mendeteksi dan mencari tahu. Faktor pelayanan dari operator menurut Ramonasari (1997) ada hubungan antara pelayanan yang baik dengan kepatuhan penderita dalam menjalani perawatan berulang (Widagdo, 2003).

Kyngas (2000) menemukan bahwa beberapa hal yang mempengaruhi kepatuhan dapat berupa faktor internal dan eksternal. Faktor internal diantaranya usia, kesan terhadap penyakitnya berupa motivasi, emosi, keinginan untuk sampai pada tujuan perawatan. Rasionalisasi akan pengobatan yang berhubungan dengan hasil perawatan, sementara faktor eksternal berupa kondisi lingkungan sosial ekonomi, dukungan orang sekitar, rencana pengobatan yang melibatkan petugas kesehatannya, adanya pemahaman tentang intervensi perawatan yang akan diterima.

Motivasi memiliki peranan penting karena motivasi merupakan dorongan dari dalam diri seseorang yang menyebabakan orang melakukan suatu kegiatan tertentu untuk mencapai tujuan yang diinginkan (Notoadmodjo, 2007). Dalam hal ini, motivasi yang dimaksud adalah motivasi penderita yang datang ke UPF Konservasi Gigi RSGMP Fakultas Kedokteran Gigi Universitas Airlangga untuk melakukan perawatan, apakah penderita datang dengan keinginannya atau oleh ajakan orang lain. Faktor motivasi ini memiliki pengaruh yang kuat terhadap kepatuhan penderita dalam menjalani perawatan (Kyngas, 2000). Teori tersebut terbukti dengan hasil uji statistik yang dilakukan bahwa nilai $\mathrm{p}$ motivasi sebesar 0,006 . Hasil ini menunjukkan bahwa ada hubungan yang signifikan antara motivasi dan kepatuahan penderita dalam menjalani perawatan berulang. Sudarma (2008) menyebutkan bahwa dorongan utama seseorang bersedia melakukan praktik pengobatan yaitu adanya need for health, tingginya dorongan untuk sehat yang ada dalam diri menyebabkan dapat mengabaikan masalah hambatan ekonomi, sosial maupun lainnya.

Persepsi adalah pemberian makna pada suatu stimulus, dengan menyimpulkan berbagai informasi dan menafsirkannya. Persepsi penderita berbeda satu dengan yang lain, contohnya saja penderita dengan penyakit yang sama, satu 
penderita mempersepsikan apa yng dirasakannya sebagai suatu penyakit sedangkan orang yang lain mempersepsikan apa yang dirasakannya bukanlah merupakan suatu penyakit (Notoadmodjo, 2007). Dari persepsi ini nantinya akan menimbulkan suatu kepercayaan atau keyakinan terhadap diri seseorang terhadap suatu penyakit. Hal ini sejalan dengan hasil penelitian yang menunjukkan bahwa nilai $\mathrm{p}$ persepsi penderita pada perawatan berulang di UPF Konservasi Gigi RSGMP Fakultas Kedokteran Gigi Universitas Airlangga sebesar 0,018 . Penderita harus percaya bahwa jika penyakit yang dideritanya tidak segera dirawat akan menimbulkan komplikasi yang lebih serius, sehingga penderita harus mengikuti perawatan yang telah direncanakan oleh petugas kesehatan. ${ }^{4}$

Biaya perawatan sangat menentukan kepatuhan penderita dalam menjalani perawatan, terutama pada perawatan penyakit kronis dan pada perawatan yang membutuhkan waktu lama dan berulang, seperti pada perawatan yang ada di UPF UPF Konservasi Gigi RSGMP Fakultas Kedokteran Gigi Universitas Airlangga. Pada penelitian ini $\mathrm{p}$ pembiayaan yang didapat pada uji statistik sebesar 0,034. Hasil tersebut mengindikasikan bahwa ada hubungan yang signifikan antara nilai pembiayaan dan kepatuhan. Hal ini sejalan dengan penelitian Skinner (1938) bahwa faktor eksternal seperti biaya berpengaruh pada perjalanan perawatan seseorang. ${ }^{12}$

Dilihat dari faktor kebutuhan dapat dilihat sebanyak $60 \%$ penderita datang mencari perawatan untuk meredakan rasa sakitnya, tanpa harus dilakukan perawatan lanjutan, dan hanya $40 \%$ yang menginginkan perawatan lanjutan hingga tuntas. Hasil uji statistik menunjukkan bahwa terdapat hubungan yang signifikan antara kebutuhan dan tingkat kepatuhan dari responden, dengan nilai signifikansi $\mathrm{p}=0,020$ Kebutuhan yang dirasakan oleh penderita berhubungan dengan motivasi dan persepsi dari seseorang, sehingga akan mempengaruhi tingkat kepatuhan penderita. ${ }^{13,15}$ Sesuai dengan teori pertukaran sosial dalam hubungan interpersonal, menyatakan bahwa seseorang berhubungan dengan orang lain karena mengharapkan sesuatu untuk memenuhi kebutuhannya. ${ }^{14,15}$

Dari hasil penelitian dapat disimpulkan bahwa tindakan kesehatan gigi dan mulut penderita tidak berhubungan secara signifikan terhadap kepatuhan penderita dalam menjalani perawatan berulang.

\section{DAFTAR PUSTAKA}

1. Badan Penelitian Dan Pengembangan Kesehatan. 2007. Riset kesehatan dasar Jakarta; Departemen Kesehatan RI.

2. Departemen Kesehatan RI. 2000. Pedoman pelayanan kesehatan gigi dan mulut. Jakarta: Departemen Kesehatan RI.

3. Budiharto. 2009. Pengantar Ilmu Perilaku Kesehatan dan pendidikan Kesehatan Gigi. Jakarta: EGC.

4. Notoadmodjo, Soekidjo. 2007. Promosi kesehatan \& ilmu perilaku. Jakarta: Rineka Cipta.

5. Walton, Torabinejad. 2002. Principles and Practice of Endodntics. $3^{\text {rd }}$ ed. Philadelphia: W.B Saunders.

6. Kyngas, H., Duffy, M.E., \& Kroll, T. 2000. Review conceptual analysis of compliance.Journal of Clinical Nursing, 9:512

7. Notoadmodjo, Soekidjo. 2005. promosi kesehatan, teori dan aplikasi. Jakarta: Rineka Cipta.

8. Notoadmodjo, Soekidjo. 2010. Ilmu perilaku kesehatan. Jakarta: Rineka Cipta.

9. Kyngas, H. 1999. A theoretical model of compliance in young diabetics. Journal of Clinical Nursing, 8:73-80.

10. Widagdo , Wahyu. 2003. Analisis faktorfaktor yang berhubungan dengan kepatuhan penderita mengenai pengobatan tuberkulosis dalam konteks keperawatan komunitas di wilayah Puskesmas Kecamatan Pasar Minggu Jakarta Selatan tahun 2002. Tesis S2. diakses tanggal 20 desember 2011 pada http://www.digilib.ui.ac.id.

11. Marzuki, 2000. Faktor-faktor yang berhubungan dengan kepatuhan berobat penderita TBC paru di puskesmas dalam wilayah kabupaten aceh besar propinsi DI Aceh tahun 998, tesis pasca UI, Jakarta.

12. Marihot Tua Effendi Hariandjaja, 2002. Manajemen Sumber Daya Manusia, Jakarta: Gramedia Widiasarana Indonesia.

13. Mitchell Alex J. and Thomas Selmes. 2007. Why Don't Patients Take Their Medicine? Reasons and Solutions in Psychiatry. Journal of Continuing Professional Development. Vol. 13, 336-346.

14. Rakhmat, Jalaluddin. 2005. Psikologi Komunikasi. Bandung: Remaja Rosdakarya.

15. Evangelista, L.S. 1999. Compliance: A concept analysis. Nursing Forum, 34 (1): 512. 